\title{
Willy Stoffregen - An early pioneer of advanced ionospheric and auroral research
}

\author{
K. Schlegel ${ }^{1}$ and H. Lühr ${ }^{2, *}$ \\ ${ }^{1}$ Copernicus Gesellschaft, Göttingen, Germany \\ ${ }^{2}$ Deutsches GeoForschungsZentrum GFZ, Potsdam, Germany \\ Correspondence to: K. Schlegel (kristian.schlegel@copernicus.org)
}

Received: 11 April 2014 - Revised: 3 June 2014 - Accepted: 9 June 2014 - Published: 4 July 2014

\begin{abstract}
We sketch the eventful life of Willy Stoffregen and summarise his engineering and scientific achievements.
\end{abstract}

\section{Life of Willy Stoffregen}

Karl Wilhelm Stoffregen, son of the construction foreman Wilhelm Stoffregen and his wife Martha, neé Richter, was born on 27 August 1909 in Bitterfeld (50 km north-west of Leipzig). From his youth he was a gifted piano player, and he earned part of his living expenses as a bar pianist during his university education (P. Stoffregen, private communication, 2014).

His academic education cannot be fully reconstructed, but it is very likely that he studied at the Technische Hochschule (Technical University) of Berlin-Charlottenburg. ${ }^{1}$

Stoffregen entered the scientific stage in 1932 when he was travelling to Norway as a staff member of the Heinrich Hertz Institute (HHI) in order to take part in the Second International Polar Year 1932/1933 (IPY). The HHI was founded in 1930 by Karl Willy Wagner (1883-1953), at that time a professor at the Technische Hochschule Berlin-Charlottenburg (Frühauf, 1954).

For this campaign Stoffregen built optical instruments and some special HF equipment for radio measurements to be operated at the Auroral Observatory in Troms $\varnothing$, Norway. The chief Norwegian scientist in this campaign was Leif Harang (1902-1970), head of the Auroral Observatory. Among other internationally renowned scientists, Edward Appleton (1892-1965) from the UK also took part in the radio measurements. Appleton and Wagner had already agreed on collaboration at the URSI General Assembly in Copenhagen in

\footnotetext{
${ }^{1}$ The enrolment records of this university were destroyed during WW2.
}

1931 (Stoffregen, 1983). Thus Stoffregen became acquainted with the most important scientists in his field. He published a summary of the activities on the occasion of the 50th anniversary of the IPY (Stoffregen, 1983).

After his return to Germany in early 1934, Stoffregen became embroiled in the affair of the accusations made by the Nazi regime towards his institute's director, Karl Willy Wagner, who refused to dismiss Jewish employees (for details, see Thoma, 1948) ${ }^{2}$. Apparently, Stoffregen defended him too briskly and found himself a target of the Nazi authorities. During an interrogation it was strongly recommended to him to leave Germany and never to come back (P. Stoffregen, private communication, 2014.). As a consequence, he was not allowed to evaluate his measurements conducted during the IPY.

Therefore Stoffregen decided to return to Norway, where he had good friends and the possibility of interesting work. With the help of Harang he received a residence permit for Norway in 1934. In 1935 he moved to Oslo to work with the company NORATEL (Larsen and Berger, 2000). At the end of 1937 he returned to Troms $\varnothing$, where he and Harang conducted pioneering work on auroral dynamics using coherent backscatter from auroras (see next section). Simultaneously he and Harang founded a company called POLAR RADIOINDUSTRIER in 1938 for producing radio communication equipment for fishing vessels (Larsen and Berger,

\footnotetext{
${ }^{2}$ Wagner was declared "enemy of the people" in 1936 and dismissed from his directorial position at the Heinrich Hertz Institute. Subsequently "Heinrich Hertz", who was Jewish, was removed from the institute's name.
} 
2000). The two colleagues developed a close friendship at that time. According to Harang, Stoffregen was a brilliant engineer but a very bad businessman. Therefore he never made much money from his inventions and never became rich (A. Egeland, private communication, 2013).

When Germany invaded Norway, Stoffregen felt endangered, and he fled to Finland on 9 June 1940. There he was interned by the Finnish authorities, but finally he received a Norwegian passport from the Norwegian government-inexile in London on 21 March 1941 (National Archives of Norway, 2013). He left Finland in the autumn of 1941 and went to Sweden as a Norwegian citizen to work at the Institute of High Voltage Research in Uppsala; its director, Harald Norinder, was a good friend of Harang. While there, Stoffregen did research on lightning discharges and developed an ionosonde (A. Egeland, personal communication, 2013).

In Uppsala, Stoffregen married Gunborg Lindgren in 1945, and the couple had two sons, Björn (born 1948) and Tore (born 1958) (B. Sannagård, private communication, 2013).

In 1946 on the recommendation of his friend Harang, Stoffregen obtained a position at the newly formed Norwegian Defence Research Establishment (NDRE). Harang was the superintendent in the telecommunication division of this organisation, which was first located in Bergen and then later moved to Kjeller in 1948. There he and Harang set up an ionosonde (A. Egeland, private communication, 2013).

In the early 1950s Stoffregen moved back to Uppsala and started regular ionosonde recordings and radar studies of the Earth's upper atmosphere for the research department of the ministry of defence. He was recommended for this position by both Harang and Appleton (A. Egeland, private communication, 2013). In 1952 he established the Uppsala Ionospheric Observatory (UIO). He headed this institute for more than two decades until his retirement in 1973. During that time he continued ionospheric research not only by means of radio methods but also by means of optical observations (see next section). In 1953 he also received Swedish citizenship. Even after his retirement, the institute kept a laboratory room for him, which he used extensively (P. Stoffregen, private communication, 2014.). The IRF honoured him with a bust in its library (Fig. 1).

In 1968 he received an honorary doctorate from Uppsala University (an honour very rarely awarded) for his pioneering work in ionospheric research (Fig. 2). For his inventiveness and his work in the International Geophysical Year (1957-1958), Stoffregen was awarded the Arnberg Prize by the Swedish Academy of Sciences, and in 1981 he received the Carl-Gustaf Rossby Research Medal by the Swedish Geophysical Society (IRF Library, 2013).

In his later years Stoffregen devoted much time to his other great interest: music. Besides playing piano, he composed classical piano pieces (Fig. 3) in the 1970s (Stoffregen, 1974a), which were occasionally played on the radio in Scandinavia (A. Egeland, private communication, 2013). It

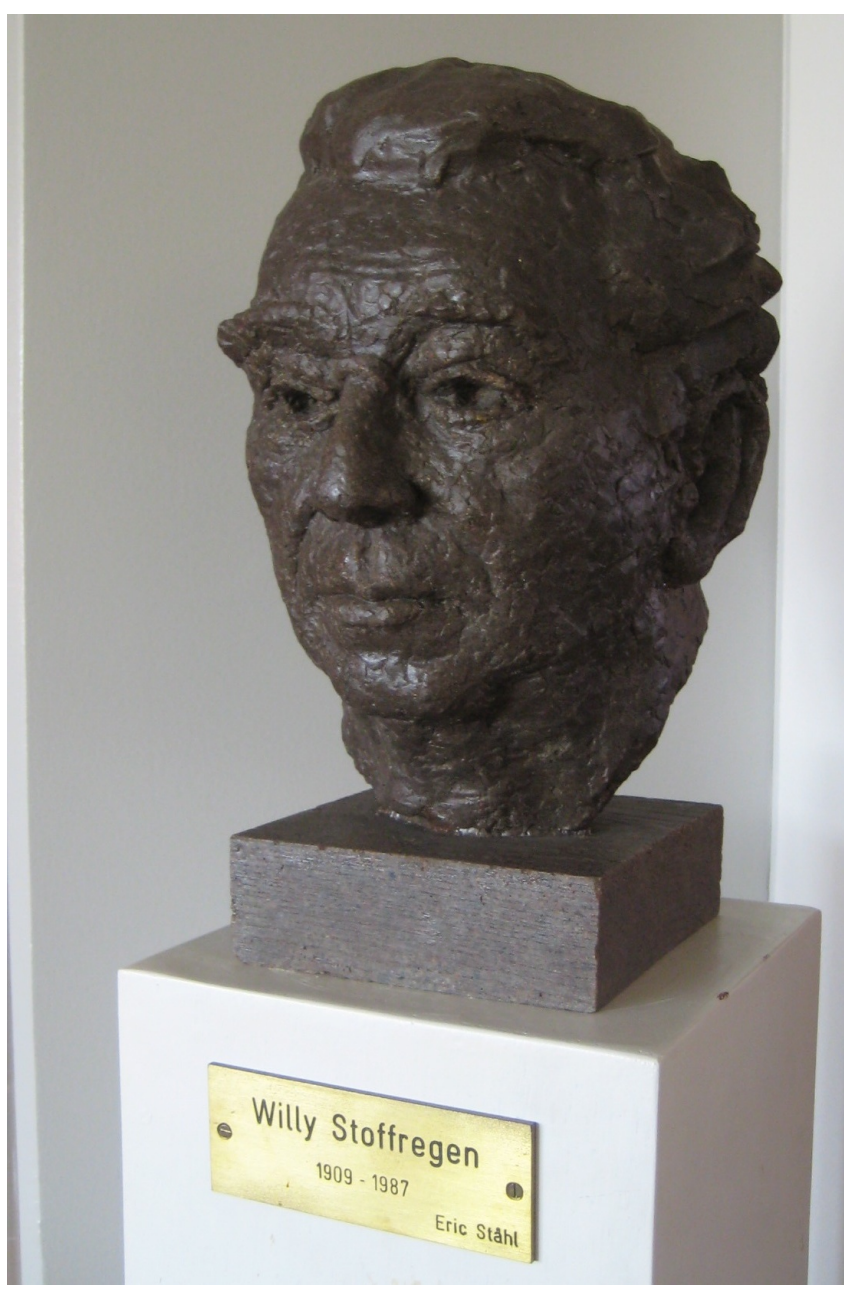

Figure 1. Bust of Willy Stoffregen in the library of the IRF.

is also worth mentioning that Stoffregen never once boarded a plane; he travelled by train, bus or ship. In the 1970s he frequently participated in the National German URSI meetings in Kleinheubach (one of the authors, K. Schlegel, was impressed by his warm and friendly attitude and his profound scientific knowledge). Stoffregen was active within URSI as early as the 1950s.

Willy Stoffregen died on 16 March 1987. Obituaries were published by his former colleague Harald Derblom and by Rolf Boström, the director of the Uppsala division of the Kiruna Geophysical Institute from 1976 (Boström and Derblom, 1987), and by Egeland and Maaseide in the Norwegian journal Fra Fysikkens Verden (1987).

\section{Scientific and engineering work of Willy Stoffregen}

In his summary about the IPY, Stoffregen (1983) pointed out that for the ionospheric pulse sounder he had built, only 


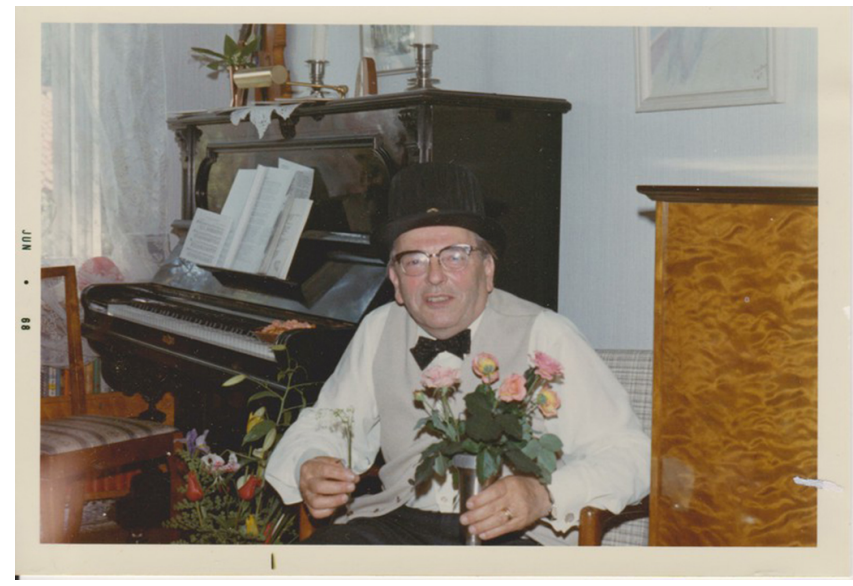

Figure 2. Willy Stoffregen at a celebration in his house after the award ceremony of the honorary doctorate of Uppsala University 1968.

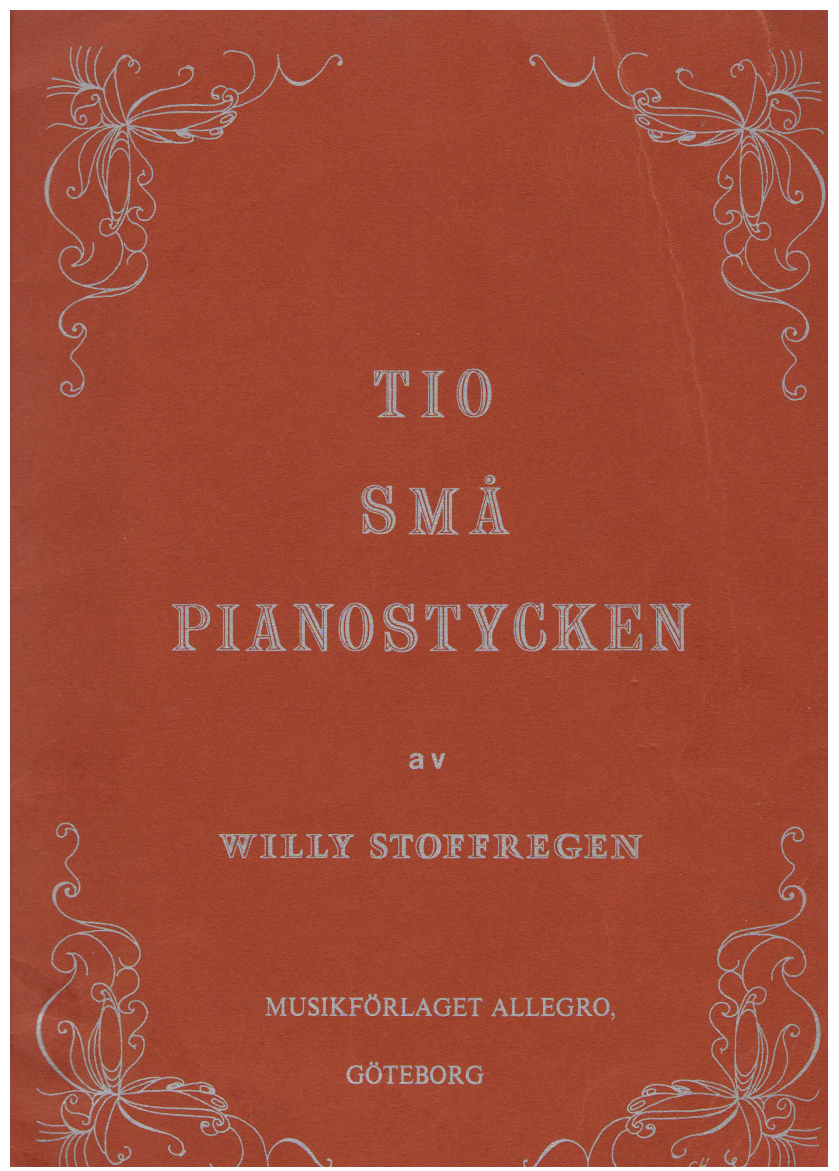

Figure 3. Title page of piano pieces composed by Stoffregen.

diodes and tetrodes were available and that cathode ray tubes for recording ionospheric echoes were very unreliable at that time. His pulse transmitter for ionospheric sounding (operating at $4 \mathrm{MHz}$ with $500 \mathrm{~W}$ power) was apparently the first permanent radio equipment at the Auroral Observatory in Troms $\varnothing$ for studying the ionosphere. Up until then, the observatory had dealt mainly with geomagnetic and optical methods. Besides the sounding, the strength and direction of signals of European broadcast stations were registered. Stoffregen and his colleague Kreielsheimer had also constructed a simple but reliable device to measure auroral luminosity. All measurements started in December 1932 and were extended to July 1934, half a year longer than originally intended. Stoffregen described all the equipment in detail in a separate paper (Stoffregen 1934); Wagner $(1933,1934)$ published results of their measurements and Fränz (1936) another detailed account.

After his return to Norway, Stoffregen and Harang performed very important measurements with another pulsed sounder constructed by Stoffregen. This sounder operated at $9 \mathrm{MHz}$, i.e. at a frequency above the F-region critical frequency, similar to what we would now call an auroral radar. Harang and Stoffregen $(1938,1940)$ published one of the first results of what is known today as coherent backscatter. Unfortunately they misinterpreted their results: assuming their echoes were received through the main lobe of their antenna (horizontal half-wave dipole), they determined the heights of the echoes to be between 850 and $1300 \mathrm{~km}$. Appleton and Naismith (1939), referring to their own results obtained during the IPY, pointed out the possibility that the echoes measured by Harang and Stoffregen might have been received through side lobes of the antenna; in this case they originated from heights between 80 and $160 \mathrm{~km}$. Harang and Landmark (1953) later re-interpreted these results correctly together with new results. Harang and Stoffregen were the first to point out the relation of these echoes to auroras, which were later called "radio aurora" (Moore, 1951). During his work at the NDRE (see Sect. 1) Stoffregen published two technical papers introducing basic concepts for ionospheric radar techniques (Stoffregen 1948a, b)

During his brief time at the Institute for High Voltage Research (Uppsala University) Stoffregen constructed an ionosonde and operated it during an observational campaign for the total solar eclipse in the north of Sweden on 9 July 1945 (Stoffregen, 1946; another publication on the solareclipse influence on the ionosphere is Stoffregen, 1955b). His ionosonde was apparently very successful: it was the first ionosonde for long-time recordings in Sweden and became the main instrument at his later-founded institute (see below). This ionosonde still exists, and is on display at IRF in Kiruna (Fig. 4) with a technical description from 1948 signed by Stoffregen (B. Holback, private communication, 2014).

The history of the establishment of the Uppsala Ionospheric Observatory is recounted by Stoffregen's later colleague Bengt Holback as follows (B. Holback, private communication, 2014):

"Willy was determined to start observing the ionosphere by means of his own built ionosonde and 




Figure 4. Ionosonde developed by Stoffregen.

by his own means. So he started to look for a suitable location in the vicinity of Uppsala. As the ionosonde operated on HF-frequencies, it was expected to interfere with radio broadcasts. Therefore it was important to find a place that was remote enough not to disturb neighbours, but still easily accessible from town. Having travelled around for some time, he came to a nice place about $8 \mathrm{~km}$ south of Uppsala centre. There he saw two beautiful girls lying in the sun with very little clothes on, and he immediately decided that this was the right place for his ionosonde (Willy's own words!). The ground belonged to the University of Uppsala and he managed to get hold of some land for his installation. So, in 1951 he started to build the station. With money from his own pocket he purchased an old container that had been used on a truck for transporting horses. This became his first lab and office and was later called 'Vita hästen' (white horse), as it was painted white. A wooden mast was erected for holding the delta antenna. In 1952, after some persuasion FOA took over responsibility for the ionosonde and its organisation".

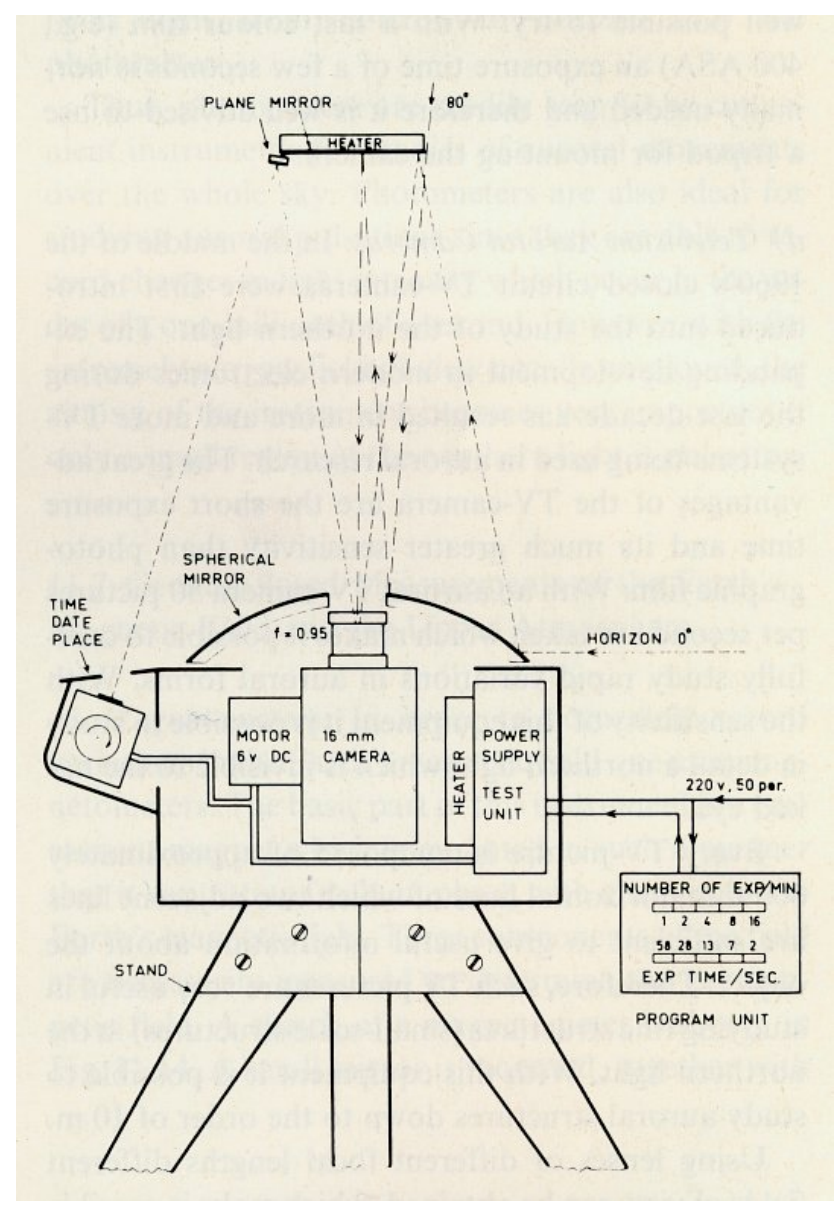

Figure 5. Block diagram of Stoffregen's all-sky camera.

FOA was the Swedish Defence Research Establishment (Försvarets Forskningsanstalt), which provided a staff position for Stoffregen. Under Stoffregen's leadership the observatory developed into a worldwide-recognised institution that succeeded in important scientific achievements. In 1976 it was integrated into the Kiruna Geophysical Institute (the name changed to Swedish Institute of Space Physics - Institutet för rymdfysik (IRF) - in 1987). The ionosonde was part of an international network (INAG).

After the war, Stoffregen turned his interest more towards optical observations of auroras. In the early 1950s he constructed the first automatic all-sky camera to be used during the International Geophysical Year 1957/1958 (IGY); this camera had a $180^{\circ}$ field of view for mapping auroral characteristics (Fig. 5). More than 100 such "Stoffregen cameras" were in use during IGY. Stoffregen (1955a) described the camera and its operation and stressed the urgent need for a network of such cameras during the IGY. He also studied the variation of auroral forms using data from a series of such cameras in Scandinavia (Stoffregen, 1961).

Another new project in close cooperation with Harang was the construction of an optical spectrometer for observing 
auroral emission lines. The spectrometer, SP3, covered a range of $350-800 \mathrm{~nm}$ with a maximal resolution of $0.1 \mathrm{~nm}$. The telescope lens had a diameter of $10 \mathrm{~cm}$, and the optical signal after the grating was recorded with a photomultiplier (Stoffregen and Derblom, 1966). With this device and together with his colleagues, Stoffregen observed and interpreted auroral oxygen emission lines (Stoffregen and Derblom, 1960), hydrogen lines (Omholt et al., 1962; Stoffregen and Derblom, 1962), helium (Stoffregen, 1969), and even lithium emissions from nuclear explosions (Stoffregen et al., 1963). In his last publication (to the best of our knowledge), he and his colleagues described optical measurements during an ionospheric heating campaign (Henriksen et al., 1984).

Stoffregen also recognised very early the potential of in situ experiments with rockets and satellites. Although he did not design and build respective experiments, he encouraged his colleagues at his institute to become active in this field (B. Holback, private communication, 2014). He thereby contributed to the spectacular success of the Swedish space science community in later years. He also participated in rocket campaigns, providing data from his ground-based optical instruments, e.g. in the barium release experiments of the MaxPlanck-Institut für Extraterr. Physik, Germany (Föppl et al., 1968, Stoffregen, 1970). The results were also published in a memorial volume to Harang (Stoffregen, 1972a). Independent of the purpose of the rocket campaign, he used the optical data for deriving neutral temperatures (Harang and Stoffregen, 1969). In addition, Stoffregen was active in the organisation of ground-based observations related to rocket campaigns in Scandinavia (Boström and Stoffregen, 1980). Even after his retirement he established and chaired the Committee for Co-Ordination of Ground-Based Observations Associated with GEOS, CCOG (Stoffregen, 1974b, 1976a, b).

There are some additional publications by Stoffregen which are worthy of mention: he studied D-region characteristics related to aurora (Stoffregen et al., 1960), auroral features of low latitudes (Stoffregen, 1962), a possible influence of the moon on auroral activity (Stoffregen, 1968), and travelling ionospheric disturbances caused by nuclear explosions (1972b).

\section{Concluding remarks}

The brief summary of Stoffregen's work given in the preceding section characterises him as an explorer with unusually wide interests. It shows that he was not only a brilliant engineer but also a broadly educated scientist who was able to properly interpret his results and establish fundamental new knowledge on ionospheric and auroral processes. Willy Stoffregen is certainly worthy of remembrance.
Acknowledgements. We thank Stoffregen's son Björn Sannagård and his nephew Peter Stoffregen for many details on the life of their father/uncle. Valuable information were also provided by Steven Pick, the Kreismuseum Bitterfeld, and another remote cousin of Stoffregen, Michael Richter. In addition we are indebted to many Scandinavian colleagues for providing facts about Stoffregen: Rolf Boström, Alv Egeland, Truls Hansen, Bengt Holback, Bengt Hultqvist, Eivind Thrane, and librarians of the IRF in Uppsala.

Edited by: R. J. Pellinen

Reviewed by: B. Hultqvist, E. Thrane, and two anonymous referees

\section{References}

We did not attempt to list all publications of Stoffregen. In addition to the contributions cited here, he published numerous internal reports at the Uppsala Ionospheric Observatory.

Appleton, E. V. and Naismith, R.: Scattering of radio waves in polar regions, Nature, 143, 243-244, 1939.

Boström, R. and Stoffregen, W: Implementation of Ground-Based Facilities to Study the Ionosphere and Magnetosphere above Scandinavia and their Role in Sounding Rocket Experiments, Fifth ESA Symposium on European Rocket and Balloon Programmes and Related Research, held 14-18 April 1980 in Bournemouth, UK. Edited by T.d. Guyenne and G. Lévy. ESASP Vol.152, 421-424, The Netherlands: ESA Scientific \& Technical Publications Branch ESTEC, 1980.

Boström, R. and Derblom, H.: Obituary Willy Stoffregen, J. Atmos. Terr. Phys. 49, p. 871, 1987

Egeland, A. and Maaseide, K: Fil. Dr. Willy Stoffregen (19091987), in: Fra Fysikkens Verden, 49, 29-30, 1987.

Föppl, H., Haerendel, G., Haser, I, Lüst, R., Melzner, F., Meyer, B., Neuss, H., Rabben, H.-H., Rieger, E., Stöcker, J., and Stoffregen, W.: Preliminary results of electric field measurements in the auroral zone, J. Geophys. Res., 73, 21-26, 1968.

Fränz, K.: Über die Funktechnische Expedition der Gesellschaft zur Föderung des Funkwesens nach Tromö und deren Ergebnisse, Zeitschr. f. Physik, 103, 671-708, 1936.

Frühauf, H.: Nachruf auf Karl Willy Wagner, Jahrb. Dt. Akad. der Wissensch. zu Berlin, Akademie Verlag Berlin, 397-404, 1956

Harang, L. and Stoffregen, W.: Scattered reflections of radio waves from a height of more than $1000 \mathrm{~km}$, Nature, 142, p. 832, 1938.

Harang, L. and Stoffregen, W.: Echoversuche auf Ultrakurzwellen, Hochfrequ. und Elektroakust., 55, 105-108, 1940.

Harang, L. and Landmark, B.: Radio echoes observed during aurorae and terrestrial magnetic storms using 35 and $74 \mathrm{Mc} / \mathrm{s}$ waves simultaneously, Nature, 171, 1017-1018, 1953.

Harang, L. and Stoffregen, W.: Upper atmosphere temperatures deduced from spectra of $\mathrm{BaO}$ recorded during barium release experiments, Planet. Space Sci., 17, 261-265, 1969.

Henriksen, K., Stoffregen, W., Lybekk, B., and Steen A:, Photometer and spectrometer search of the oxygen green and red lines during artificial ionospheric heating in the auroral zone, Ann. Geophys., 2, 73-75, 1984, http://www.ann-geophys.net/2/73/1984/.

Larsen, R. and Berger, S: Nordlysobservatoriet - historier og erindringer, University of Troms $\varnothing, 2000$ 
Moore, R. K.: A V.H.F. propagation phenomena associated with aurora, J. Geophys. Res. 56, 97-106, 1951.

Omholt, A., Stoffregen, W., and Derblom, H.: Hydrogen lines in auroral glow, J. Atmos. Terr. Phys., 24, 203-209, 1962.

Stoffregen, W.: Apparate und Registrierverfahren der funktechnischen Expedition in Tromsö der Gesellschaft zur Förderung des Funkwesens, Berlin, Elektr. Nachrichtentechnik, 11, 341-350, 1934.

Stoffregen, W.: Records of the ionosphere during the total eclipse in the north of Sweden on July 9, 1945, Terr. Magnet. and Atmosph. Electri., 51, 495-499, 1946.

Stoffregen, W.: A Panoramic Ionospheric Echo Recorder, Terr. Magnet. Atmos. Electricity, 53, 269-271, 1948a.

Stoffregen, W.: Ionosphere Reflections Recorded Mechanically by Means of a Repetition Frequency Converter, J. Appl. Phys. 19, 487-490, 1948b.

Stoffregen, W.: All-Sky Camera Auroral Research during the Third Geophysical Year 1957-58, Tellus, 7, 509-517, 1955a.

Stoffregen, W.: Variation of fEs during solar eclipses, Nature, 176, p. $610,1955 \mathrm{~b}$.

Stoffregen, W.: Radio reflections of low frequencies from 75-90 km's height during intense aurora activity. J. Atmos. Terr. Phys., 13, 167-169, 1958.

Stoffregen, W.: The east-west drift of auroral forms determined from all-sky camera films, J. Atmos. Terr. Phys., 21, 257-260, 1961.

Stoffregen, W.: Some Auroral and Ionospheric Features More Typical for Lower Latitudes than the Auroral Zone, in: Electron Density Profiles in the Ionosphere and Exosphere, Proceedings of the NATO Advanced Study Institute held at Skeikampen, Norway, April, 1961, edited by: Maehlum, B., p. 55, New York, Press Book, 1962.

Stoffregen, W.: On the influence of the moon on the auroral activity, Ann. de Géophys. 24, 57-61, 1968.

Stoffregen, W.: Transient emissions on the wavelength of helium I, $5876 \AA$ A recorded during auroral break-up, Planet. Space Sci., 17, 1927-1935, 1969.

Stoffregen, W.: Electron density variation observed in the E-layer below an artificial barium cloud, J. Atmos. Terr. Phys., 32, 171$177,1970$.

Stoffregen, W.: Electron-density increase in the E-layer below an artificial Barium cloud. Geofysiske Publikasjoner (Universitetsforlaget) 29, 151-156, 1972a.

Stoffregen, W.: Travelling Ionospheric Disturbances Initiated by Low Altitude Nuclear Explosions, Effects of Atmospheric Acousitic Gravity Waves on Electromagnetic Wave Propagation, Papers presented at the Specialist Meeting of the Electromagnetic Wave Propogation Panel of AGARD held 17-21 April 1972 at Wiesbaden, West Germany. p. 35, London: Harford House, October, 1972 b.
Stoffregen, W.: Tio små pianostycken, Allegro, Göteborg (circa 1974), 1974a.

Stoffregen, W.: Work carried out by the CCOG, European Sounding-Rocket and Scientific-Balloon Activity at High Latitudes, with Emphasis on the International Magnetospheric Study (IMS). Proceedings of the Symposium held 9-12 September 1974, at Orenäs Slott, Sweden, p.141, Published by Organisation Europeenne de Recherches Spatiales, Neuilly, France, 1974b.

Stoffregen, W.: Short report from CCOG, Committee for CoOrdination of Ground-Based Obserevations Associated with GEOS, European programmes on sounding-rocket and balloon research in the auroral zone, Proceedings of a symposium held at Schloss, Elmau, German, 3-7 May 1976, European Space Agency, ESA SP-115, 355-358, 1976a.

Stoffregen, W. (Ed.): CCOG Handbook for the IMS-GEOS (Period 1976-79), Circ. Lett. 7, 196 p., Comm. for Coord. of Observ. Ass. with GEOS, Uppsala, Sweden, 1976b.

Stoffregen, W.: The Heinrich-Hertz-Institute expedition to Troms $\emptyset$ during the International Polar Year 1932-33, Ann. Geophys., 1, 387-390, 1983, http://www.ann-geophys.net/1/387/1983/.

Stoffregen, W. and Derblom, H.: Lifetime of the atomix oxygen 6300 A line in the auroral spectrum, Nature, 185, 28-29, 1960.

Stoffregen, W. and Derblom, H: Auroral hydrogen emission related to charge separation in the magnetosphere, Planet. Space Sci., 9, 711-712, 1962.

Stoffregen, W. and Derblom, H.: Some instruments for night studies of upper atmosphere light emeissions, in: Rocket experiments for studies of the D-region ion concentration and emission from released chemicals in twilight aurora, Rpt. No. 15, Uppsala Jonosfärobservatorium, Uppsala, 1966.

Stoffregen, W., Derblom, H., and Omholt, A.: Some Characteristics of the D-Region Ionization during Auroral Activity, J. Geophys. Res., 65, 1699-1704, 1960.

Stoffregen, W., Derblom, H., and Ånger, B.: Lithium emission in twilight at Uppsala during November 1962, Nature, 197, 783785, 1963.

Thoma, A.: Laudatio Willy Wagner, Archiv elektr. Übertr., 2, 117119, 1948.

Wagner, K. W.: Vorläufige Ergebnisse der funktechnischen Expedition der Heinrich-Hertz-Gesellschaft nach Tromsö (Norwegen), Sitzber. Preuß. Akad. Wiss. (Phys.-math. KL), XXXI, XXXII, p. 910, 1933.

Wagner, K. W.: Die funkwissenschaftliche Expedition der HeinrichHertz-Gesellschaft nach Tromsö (Norwegen), Elektr. Nachr.Techn., 11, 37, 1934. 